\title{
Nuclear Factor- $\kappa$ B Regulates Cyclooxygenase-2 Expression and Cell Proliferation in Human Gastric Cancer Cells
}

\author{
Joo Weon Lim, Hyeyoung Kim, and Kyung Hwan Kim \\ Department of Pharmacology and Institute of Gastroenterology, Brain Korea 21 Project for Medical Sciences, \\ Yonsei University College of Medicine, Seoul, Korea
}

\begin{abstract}
SUMMARY: Nuclear factor $-\kappa \mathrm{B}(\mathrm{NF}-\kappa \mathrm{B})$ is a transcriptional regulator of inducible expression of genes including cyclooxygenase-2 (COX-2), regulating cell proliferation. NF- $\kappa \mathrm{B}$ is kept silent in the cytoplasm via interaction with the inhibitory protein $I_{\kappa} \mathrm{B} \alpha$ and transmigrated into the nucleus upon activation. However, constitutive NF- $\kappa \mathrm{B}$ has been found in the nucleus of some cancer cells. We investigated the role of NF- $\kappa \mathrm{B}$ in COX-2 expression and cell proliferation in human gastric cancer AGS cells. AGS cells were treated with antisense oligodeoxynucleotide (AS ODN) or sense oligodeoxynucleotide (S ODN) for the NF- $\kappa \mathrm{B}$ subunit $\mathrm{p} 50$, or they were transfected with a mutated $\mathrm{I}_{\kappa} \mathrm{B} \alpha$ gene (MAD-3 mutant) or a control vector, pcDNA-3. AGS cells were treated with COX-2 inhibitors such as indomethacine and NS-398 or prostaglandin $E_{2}$. mRNA expression for COX-2, and protein levels for $\mathrm{p} 50, I_{\kappa} \mathrm{B} \alpha$, and $\mathrm{COX}-2$ were determined by reverse transcription polymerase chain reaction and Western blot analysis. The NF- $\kappa \mathrm{B}$ levels were examined by electrophoretic mobility shift assay. Thromboxane $\mathrm{B}_{2}\left(\mathrm{TXB}_{2}\right)$ and $6-k e t o-$ prostaglandin $F_{1 \alpha}$ (6-keto-PGF $F_{1 \alpha}$ ) levels were determined by enzyme-linked immunosorbent assay. Cell proliferation was assessed by viable cell counting, $\left[{ }^{3} \mathrm{H}\right]$ thymidine incorporation, and colony formation. The nuclear level of p50 decreased in AGS cells treated with AS ODN. The $I_{\kappa} \mathrm{B} \alpha$ mutant was observed in cells transfected with the mutated $I_{\kappa} \mathrm{B} \alpha$ gene. NF- $\kappa \mathrm{B}$ was inhibited in cells treated with $A S O D N$ or transfected with the mutated $I_{\kappa} B \alpha$ gene, compared with the cells treated with $S$ ODN or transfected with control vector. Cell proliferation, mRNA expression and protein level of COX-2, and production of TXB ${ }_{2}$ and 6-keto-PGF ${ }_{1 \alpha}$ were inhibited in cells treated with AS ODN or transfected with the mutated $I_{\kappa} \mathrm{B} \alpha$ gene, which had lower NF- $\kappa \mathrm{B}$ levels than cells treated with S ODN or transfected with control vector. COX-2 inhibitors suppressed cell proliferation and production of $\mathrm{TXB}_{2}$ and 6-keto-PGF ${ }_{1 \alpha}$, in a dose-dependant manner. Prostaglandin $\mathrm{E}_{2}$ prevented the inhibition of proliferation in cells treated with AS ODN or transfected with the mutated $I_{\kappa} \mathrm{B} \alpha$ gene. In conclusion, NF- $\kappa$ B mediates COX-2 expression, which may be related to cell proliferation, in human gastric cancer cells. (Lab Invest 2001, 81:349-360).
\end{abstract}

$M$ any cellular genes involved in the early process of immune, acute phase, and inflammatory responses are regulated at the level of transcription by nuclear factor $-\kappa \mathrm{B}(\mathrm{NF}-\kappa \mathrm{B})$ (Baeuerle and Baltimore, 1996; Barnes and Karin, 1997). Several reports have shown a role for NF- $\kappa \mathrm{B}$ gene products in cell proliferation, transformation, and tumor development (Siebenlist et al, 1994; Wulczyn et al, 1996). NF- $\kappa$ B is an inducible transcription factor that mediates signal transduction between the cytoplasm and nucleus in many cell types (Baeuerle and Henkel, 1994). NF- $\kappa$ B is a member of the Rel family, which includes p50 (NF- $\kappa$ B1), p52 (NF- $\kappa$ B2), Rel A (p65), c-Rel, rel B, and Drosophila morphogen dorsal gene product (Siebenlist et al, 1994). In resting cells, NF- $\kappa \mathrm{B}$ is localized in the cytoplasm as a hetero- or homodimer, and is noncovalently associated with cytoplasmic inhibitory proteins, including $I_{\kappa} \mathrm{B}$. Upon stimulation by a variety

Received November 13, 2000.

This work was supported by Grant HMP-00-CH-02-0002 from the Korean Ministry of Health and Welfare.

Address reprint requests to: Dr. Hyeyoung Kim, Department of Pharmacology, Yonsei University College of Medicine, Seoul 120-752, Korea. E-mail: kim626@yumc.yonsei.ac.kr of pathogenic inducers, such as viruses, mitogens, bacteria, agents providing oxygen radicals, and inflammatory cytokines, the NF- $\kappa \mathrm{B}$ complex migrates into the nucleus and binds DNA recognition sites in the regulatory regions of the target genes (Thanos and Maniatis, 1995). In most resting-state mammalian cells, NF- $\kappa \mathrm{B}$ is inactive. However, NF- $\kappa \mathrm{B}$ was aberrantly activated in human breast cancer and in rat mammary tumors from the aromatic hydrocarboninduced model of breast cancer under resting state, whereas low levels of NF- $\kappa$ B were found in untransformed human breast epithelial cells and normal rat mammary glands (Sovak et al, 1997; Wu et al, 1996). Furthermore, the inhibition of constitutive NF- $\kappa$ B in B cell lymphomas and breast cancer cell lines leads to the induction of apoptosis (Sovak et al, 1999; Wu et al, 1996). Thus, NF- $\kappa$ B proteins could be directly involved in cell proliferation. Our previous studies (Kim et al, $1999,2000)$ demonstrated that a constitutive level of $\mathrm{NF}-\kappa \mathrm{B}$ was observed in the nucleus of gastric carcinoma AGS cells. NF- $\kappa$ B dimers (a p50/p65 heterodimer and a p50 homodimer) were detected in these cells and the major NF- $\kappa \mathrm{B}$ band was a p50 homodimer, even in resting-state cells. Upon stimulation by Helicobacter pylori infection, a p50/p65 het- 
erodimer was highly elevated and a p50 homodimer was slightly increased in the nucleus of AGS cells.

$\mathrm{NF}-\kappa \mathrm{B}$ activation is tightly regulated by its endogenous inhibitor, $I_{\kappa} \mathrm{B}$, which complexes NF- $\kappa \mathrm{B}$ in the cytoplasm. To date, the most extensively studied $I_{\kappa} \mathrm{B}$ protein is $I_{\kappa} \mathrm{B} \alpha(36 \mathrm{kd})$, which is encoded by the human MAD-3 gene or its homologues in different species (Haskill et al, 1991). The mechanisms that lead to the degradation of $\mathrm{I}_{\kappa} \mathrm{B} \alpha$ proteins are poorly understood, but involve changes in the phosphorylation state of $I_{\kappa} \mathrm{B} \alpha$ (Le Bail et al, 1993; Thanos and Maniatis, 1995). Two serines in the $\mathrm{N}$-terminal domain of $\mathrm{I}_{\kappa} \mathrm{B} \alpha$, serine residues 32 and 36 , are critical for $I_{\kappa} \mathrm{B} \alpha$ stability (Brown et al, 1995). Substitution of these two serine residues by alanine residues renders $I_{\kappa} \mathrm{B} \alpha$ undegradable by cellular activators (Brown et al, 1995; Traenckner et al, 1995). Among many proteins exhibiting $I_{\kappa} B$ function, $I_{\kappa} \mathrm{B} \alpha$ is the only inhibitor that dissociates from the NF- $\kappa \mathrm{B}$ complex in response to cell stimulation, with kinetics matching NF- $\kappa \mathrm{B}$ translocation to the nucleus (Sun et al, 1994). Therefore, it was suggested that the activation of NF- $\kappa \mathrm{B}$ is regulated by $\mathrm{NF}-\kappa \mathrm{B} /$ $\mathrm{I} \kappa \mathrm{B} \alpha$ dissociation (Beg and Baldwin, 1993; Liou and Baltimore, 1993). Mutant $\mathrm{I} \kappa \mathrm{B} \alpha$ acts as an NF- $\kappa \mathrm{B}$ super-repressor (Wang et al, 1996).

Antisense oligodeoxynucleotides (AS ODN) are small, synthetic molecules, 15 to 25 base pairs in length, and are usually single-stranded DNA complementary to the mRNA transcribed from the target gene. Formation of a duplex structure occurs through base-pairing between the antisense DNA and its target mRNA, inhibiting gene expression (Milligam et al, 1993). Postulated mechanisms of AS ODN include steric hindrance of gene transcription or gene translation, blockage of mRNA processing or splicing, and degradation of mRNA through the action of RNase $\mathrm{H}$ activity (Crooke, 1992). Oligodeoxynucleotides (ODN) can be chemically manipulated by replacement of a nonbridging oxygen with sulfur in a phosphate linkage to form phosphorothioate-modified ODN, making ODN more resistant to degradation by nucleases (Brown et al, 1994). Thus, AS ODN can be made to bind to a single gene or its transcription product and act within the constraints of that gene's expression, minimizing side effects. As mentioned above, two species of $\mathrm{NF}-\kappa \mathrm{B}$ dimers (a p50/p65 heterodimer and a p50 homodimer) are present in activated gastric cancer cells (Keates et al, 1997; Kim et al, 1999). Thus, as a choice for targeting by AS ODN, p50 offers the best potential for effecting NF- $\kappa \mathrm{B}$ expression and the genes that $\mathrm{NF}-\kappa \mathrm{B}$ regulates.

Cyclooxygenase, the enzyme that catalyzes the oxidation of arachidonic acid, is expressed in two isoforms, cyclooxygenase-1 (COX-1) and cyclooxygenase-2 (COX-2). COX-1 is constitutively expressed in most tissues and is thought to be important in maintaining cellular homeostasis (O'Neil and Hutchinson, 1993). In contrast, COX-2 is frequently undetectable at baseline in normal tissues, but readily expressed in gastrointestinal epithelial cells in response to inflammatory cytokines, lipopolysaccharide, mitogens, and oxygen radicals (Williams and Du
Bios, 1996). The role of COX-2 in gastric tissue is uncertain. However, prostaglandins produced via COX-2, including prostaglandin $\mathrm{E}_{2}\left(\mathrm{PGE}_{2}\right)$ (Hida et al, 1998; Tjandrawinata et al, 1997), prostaglandin $A_{1}, A_{2}$, and $D_{2}$ (Bhuyan et al, 1986), prostaglandin $J_{2}$ and 15-deoxy-delta 12,14-prostaglandin $\mathrm{J}_{2}$ (Chinery et al, 1999), are believed to be the major contributors to cell proliferation and the inflammatory process (Seibert et al, 1994, 1995). They can be mutagenic (Plummer et al, 1995) and tumorigenic (Boolbol et al, 1996). Therefore, chronic expression of COX-2 may play an important role in gastric carcinogenesis in addition to propagation of gastric inflammation. Zimmermann et al (1999) reported that $\mathrm{PGE}_{2}$ synthesis was 600 times higher in human esophageal carcinoma cell lines. They showed high COX-2 expression that was directly related to cell proliferation. $\mathrm{PGE}_{2}$ has been regarded as a primary COX-2 product in smooth muscle cells (Yamamoto et al, 1999), colon carcinoma cells (Kojima et al, 2000), lung cancer cells (Hida et al, 1998), esophageal cancer cells (Zimmermann et al, 1999), and prostatic carcinoma cells (Tjandrawinata et al, 1997). COX-2 is constitutively expressed in certain groups of cancers (Battu et al, 1998; Sheng et al, 1997) and is related to the cell proliferation in those cancers (Higashi et al, 2000; Molina et al, 1999). COX-2 inhibition by specific COX-2 inhibitors suppresses cell proliferation and induces apoptosis in pancreatic cancer cells (Ding et al, 2000) and in a colorectal cancer cell line (Elder et al, 1997; Hara et al, 1997). However, in gastric cancer cells, COX-2 inhibition did not induce apoptosis, it only inhibited cell proliferation (Sawaoka et al, 1998). However, there have been no direct studies of the relation among transcription factors regulating COX-2 expression and cell proliferation or apoptosis in cancer cells. The promoter region of the human COX-2 gene contains two NF- $\kappa \mathrm{B}$ consensus sites, and the expression of COX-2 is largely regulated by NF- $\kappa \mathrm{B}$ in several cells (Hla and Neilson, 1992; Yamamoto et al, 1995). Because some evidence supports a role of NF- $\kappa$ B in the COX-2 expression that regulates cell proliferation (Gallois et al, 1998; Kojima et al, 2000), we hypothesize that inhibition of constitutive NF- $\kappa \mathrm{B}$ may suppress COX-2 expression and thus, cell proliferation, in human gastric cancer cells.

We conducted the present study to evaluate the role of NF- $\kappa \mathrm{B}$ on COX-2 expression and cell proliferation in gastric cancer AGS cells by treating AS ODN for p50 or transfecting mutated $I_{\kappa} \mathrm{B} \alpha$ genes (MAD-3 double point mutation at positions 32 and 36 ) to inhibit NF- $\kappa$ B activation. To evaluate the relationship between COX-2 expression and cell proliferation, AGS cells were treated with COX-2 inhibitors, such as indomethacine and NS-398 or $\mathrm{PGE}_{2}$, and cell proliferation was determined. After treatment with AS ODN for p50 or transfection with the mutated $I_{\kappa} \mathrm{B} \alpha$ gene, the levels of p50 and $I_{\kappa} \mathrm{B} \alpha \mathrm{s}$ and NF- $\kappa \mathrm{B}$ activation were determined by Western blot analysis and electrophoretic mobility shift assay (EMSA). Levels of COX-2 mRNA and protein were determined by reverse transcription polymerase chain reaction (RT-PCR) and Western blot 
analysis. Stable COX-2 products, thromboxane $B_{2}$ $\left(\mathrm{TXB}_{2}\right)$ and 6-keto-prostaglandin $\mathrm{F}_{1 \alpha}$ (6-keto-PGF $\left.\mathrm{F}_{1 \alpha}\right)$ were determined by enzyme-linked immunosorbent assay (ELISA). Cell proliferation was assessed by viable cell counting, $\left[{ }^{3} \mathrm{H}\right]$ thymidine incorporation, and colony formation.

\section{Results}

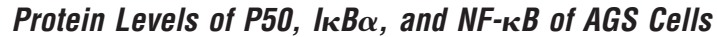

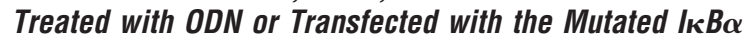 Gene}

To inhibit NF- $\kappa$ B activation, the cells were treated with AS ODN or sense oligodeoxynucleotide (S ODN) for 72 hours (Figs. $1 \mathrm{~A}$ and $2 \mathrm{~A}$ ), or transfected with control pcDNA3 vector $(\mathrm{pcN}-3)$ or the mutated $\mathrm{I}_{\kappa} \mathrm{B} \alpha$ gene (IW-6 and IW-10) (Figs. 1B and 2B). The effect of AS ODN treatment was assessed by measuring the level of p50 protein in the nucleus. Western blot analysis for p50 showed that AS ODN caused a reduction in p50 protein compared with control cells and cells treated with S ODN (Fig. 1A). NF- $\kappa \mathrm{B}$ levels in the nuclear extracts of cells treated with AS ODN were lower than in control cells or cells treated with S ODN (Fig. 2A).

AGS cells were stably transfected with a mutated $\mathrm{I}_{\kappa} \mathrm{B} \alpha$ gene, which is not susceptible to phosphorylation at positions 32 and 36 , and resists degradation in transient transfection (Le Bail et al, 1993). The stably transfected clones of the control vector $(\mathrm{pcN}-3)$ and of the mutated $I_{\kappa} \mathrm{B} \alpha$ gene (IW-6, IW-10), were selected and analyzed by Western blot analysis for mutated $I_{\kappa} \mathrm{B} \alpha$ expression (Fig. 1B). In control cells and cells transfected with pcN-3, two bands had an electrophoretic mobility of 36 and $38 \mathrm{kd}$, corresponding to wild-type $I_{\kappa} \mathrm{B} \alpha \quad\left(I_{\kappa} \mathrm{B} \alpha\right.$ wt) and phosphorylated $I_{\kappa} \mathrm{B} \alpha$ $\left({ }_{\kappa} \mathrm{B} \alpha-\mathrm{P}\right)$, respectively. In the cells transfected with the mutated $I_{\kappa} \mathrm{B} \alpha$ gene (IW-6 and IW-10), a major band (38 kd) was detected with a specific $I_{\kappa} \mathrm{B} \alpha$ antibody. It was

A p50

Control AS S

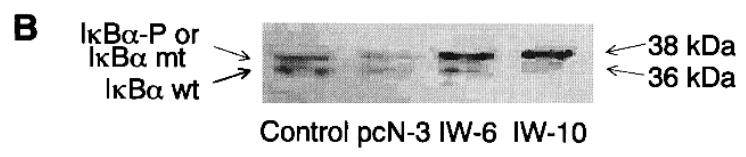

Figure 1.

Western blot analysis for $p 50$ and $I_{\kappa} B \alpha$ of AGS cells treated with oligodeoxynucleotide (ODN) or transfected with the mutated $I_{\kappa} \mathrm{B} \alpha$ gene. For p50 analysis, cells were treated with antisense $(A S)$ ODN or sense $(S)$ ODN for 72 hours, and $20 \mu \mathrm{g}$ of nuclear protein were subjected to $8 \%$ SDS-PAGE and transferred onto membrane. The NF- $\kappa$ B subunit $\mathrm{p} 50$ was visualized with p50-specific antibody $(A)$. For $I_{\kappa} \mathrm{B} \alpha$ analysis, cells were transfected with a control pcDNA3 vector $(p c N-3)$ or the mutated $I_{\kappa} B \alpha$ gene $(I W-6$ and $I W-10)$, and cell lysates (100 $\mu \mathrm{g}$ of protein) were subjected to $8 \%$ SDS-PAGE and transferred onto membranes. Wild-type $I_{\kappa} \mathrm{B} \alpha\left(I_{\kappa} B \alpha w t\right)$, phosphorylated $I_{\kappa} \mathrm{B} \alpha$ $\left(I_{\kappa} B \alpha-P\right)$, and mutant-type $I_{\kappa} B \alpha\left(I_{\kappa} B \alpha m t\right)$ were visualized with specific antibodies. Arrows indicate the two bands with electrophoretic mobilities of 36 and $38 \mathrm{kd}(B)$. Control cells received neither treatment nor transfection (Contro). reported that transfection with a mutated $I_{\kappa} \mathrm{B} \alpha$ gene generated a reduced electrophoretic mobility product corresponding to a $38 \mathrm{kd}$ band (Cai et al, 1997; Jobin et al, 1998). Thus, the slower migration band (38 kd) probably corresponded to the product of the mutated $I_{\kappa} \mathrm{B} \alpha$ gene (mutant-type $\left.I_{\kappa} \mathrm{B} \alpha ; I_{\kappa} \mathrm{B} \alpha \mathrm{mt}\right)$. To investigate whether the introduction of an exogenous mutated $1 \kappa \mathrm{B} \alpha$ gene leads to a suppression of constitutive $\mathrm{NF}-\kappa \mathrm{B}$, we performed an EMSA with nuclear extracts from the transfected cells. As shown in Figure 2B, $\mathrm{NF}-\kappa \mathrm{B}$ levels of the cells transfected with the mutated $I_{\kappa} \mathrm{B} \alpha$ gene (IW-6 and IW-10) were significantly reduced compared with control cells or with the cells transfected with $\mathrm{pcN}-3$. Additionally, the IW-10 clone had more $I_{\kappa} \mathrm{B} \alpha$ mutant and less NF- $\kappa \mathrm{B}$ than the IW-6 clone. These results show that mutated $I_{\kappa} \mathrm{B} \alpha$ expression is directly related to inhibition of NF- $\kappa$ B activation.

\section{Cell Proliferation of AGS Cells Treated with ODN or Transfected with the Mutated IкBa Gene}

To evaluate the relationship between NF- $\kappa$ B inhibition and cell proliferation, the cells treated with ODN (Fig. $3 \mathrm{~A}$ ) or transfected with the mutated $I_{\kappa} \mathrm{B} \alpha$ gene (Fig. 3B) were cultured for 96 hours, and the cell number was counted after trypan blue exclusion. Cell proliferation decreased in the cells treated with AS ODN or transfected with the mutated $I \kappa \mathrm{B} \alpha$ gene (IW- 6 and IW-10), compared with control cells, the cells treated with S ODN, or the cells transfected with pcN-3. This result was confirmed by other methods: determining the percentage of $3(4,5$-dimethylthiazol-2-yl)-2,5diphenyltetrazolium bromide (MTT) positive cells (Fig.
A

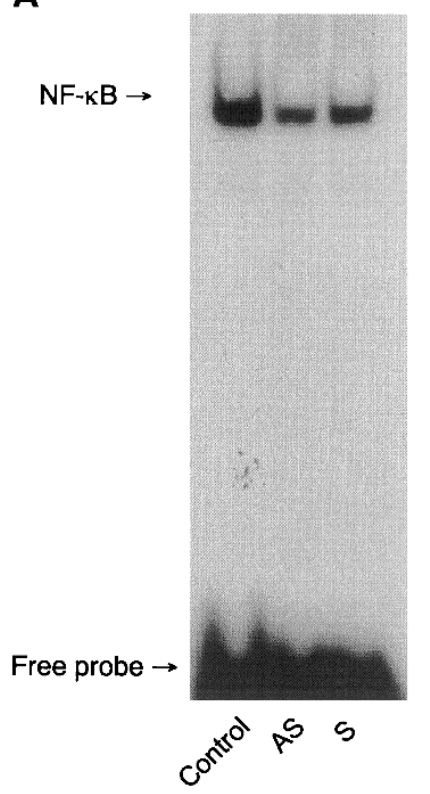

B

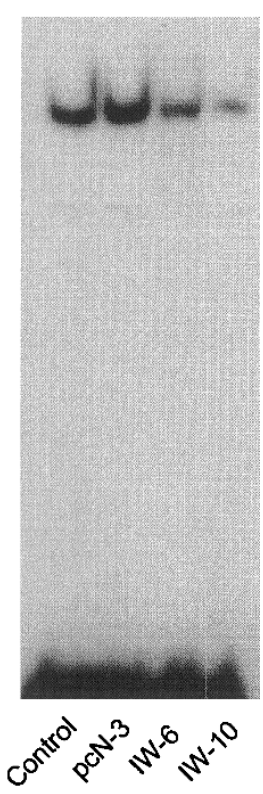

Figure 2.

$\mathrm{NF}-\kappa \mathrm{B}$ levels in the nuclei of AGS cells treated with ODN or transfected with the mutated $I_{\kappa} B \alpha$ gene. Nuclear extracts $(1 \mu \mathrm{g})$ were prepared from the cells treated with $A S$ ODN or $S$ ODN for 72 hours $(A)$, or transfected with control pcDNA3 vector $(p c N-3)$ or the mutated $I_{\kappa} B \alpha$ gene $(I W-6$ and $I W-10)(B)$, and subjected to electrophoretic mobility shift assay (EMSA). Control cells received neither treatment nor transfection (Contro). 
A

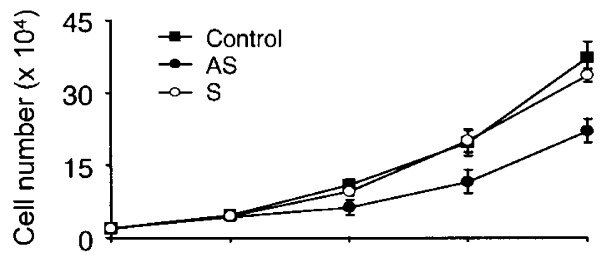

B

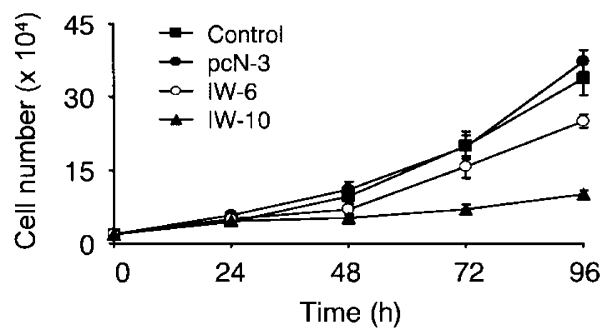

Figure 3.

Cell numbers of AGS cells treated with ODN or transfected with the mutated $I_{\kappa} \mathrm{B} \alpha$ gene. Cells were treated with AS ODN or $S$ ODN for 72 hours $(A)$ or transfected with control pcDNA3 vector $(p c N-3)$ or the mutated $I_{\kappa} B \alpha$ gene $(I W-6$ and $I W-10)(B)$. Cells, plated at $2 \times 10^{4}$ cells/well, were incubated for the indicated times and cell numbers were counted by trypan blue exclusion. Control cells received neither treatment nor transfection (Contro). Each point represents the mean \pm standard deviation of four separate experiments.

$4 \mathrm{~A}$ ), the amount of $\left[{ }^{3} \mathrm{H}\right]$ thymidine incorporation (Fig. 4B), and the degree of colony formation (Fig. 4C). After 96 hours in culture, the percentage of MTT-positive cells decreased in AS ODN-treated cells and in cells transfected with the mutated $I_{\kappa} \mathrm{B} \alpha$ gene. $\left[{ }^{3} \mathrm{H}\right]$ thymidine incorporation of the cells treated with AS ODN or transfected with the mutated $I_{\kappa} \mathrm{B} \alpha$ gene was significantly lower than in cells treated with S ODN or transfected with a control vector after 24 hours in culture. To examine the effect of NF- $\kappa$ B inhibition on colony formation, the cells were cultured in a soft agar, an ex vivo model of tumor cell growth. After 10 days in culture, control cells formed colonies with efficiency of approximately $3 \%$. Colony formation of the cells treated with AS ODN or transfected with the mutated $I_{\kappa} \mathrm{B} \alpha$ gene was significantly lower than those treated with S ODN or control vector. Inhibition of cell proliferation was lower in IW-10 cells than in IW-6 cells, determined by cell numbers, percentage of MTTpositive cells, $\left[{ }^{3} \mathrm{H}\right]$ thymidine incorporation, and colony formation. These results showed that inhibition of $\mathrm{NF}-\kappa \mathrm{B}$ activation caused a strong down-regulation of cell proliferation, which correlated with the expression level of mutated $\mathrm{I}_{\kappa} \mathrm{B} \alpha$ (Figs. 1B and 2B).

\section{mRNA Expression and Protein Level of COX-2 and Production of TXB ${ }_{2}$ and 6-Keto-PGF ${ }_{1 \alpha}$ in AGS Cells

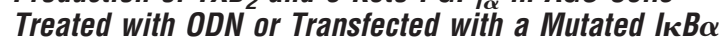 Gene}

RT-PCR analysis for mRNA expression of COX-2, standardized by co-amplifying this gene with the housekeeping gene $\beta$-actin, showed that AGS cells constitutively expressed COX-2 in resting cells. COX-2 expression was lower in the cells treated with AS ODN or transfected with the mutated $I_{\kappa} \mathrm{B} \alpha$ gene (IW-6 and IW-10) than in control cells, cells treated with S ODN, or cells transfected with pcN-3 (Fig. 5A).

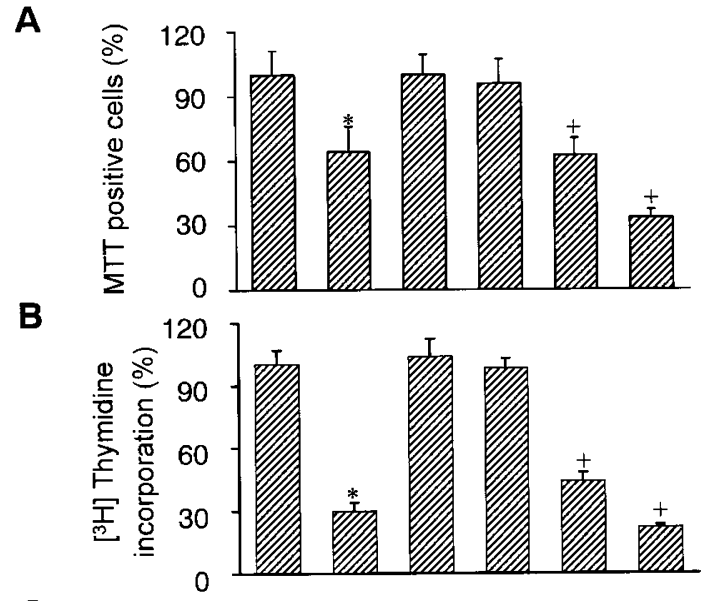

C

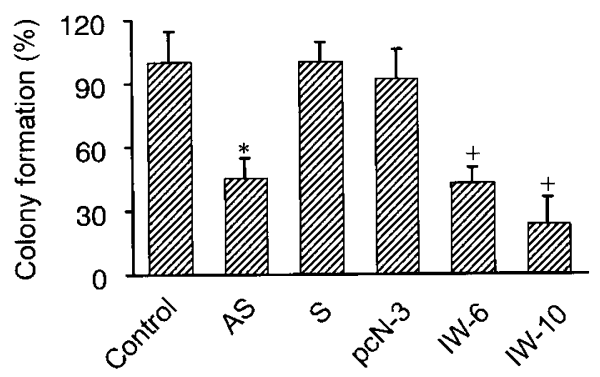

Figure 4.

Cell proliferation of AGS cells treated with ODN or transfected with the mutated $I_{\kappa} \mathrm{B} \alpha$ gene, as determined by the percentage of 3-(4,5-dimethylthiazol-2-yl)2,5-diphenyltetrazolium bromide (MTT) positive cells $(A)$, thymidine incorporation $(B)$, and colony formation $(C)$. Cells were treated with $A S$ ODN or $S$ ODN for 72 hours or transfected with control pcDNA3 vector ( $p c N-3)$ or the mutated $I_{\kappa} \mathrm{B} \alpha$ gene $(I W-6$ and $/ W-10)$. For the analysis of MTT-positive cells, cells were plated at $1 \times 10^{3}$ cells/well and cultured for 96 hours. Viable cells were assessed by MTT assay and MTT-positive cells were expressed as a percentage of control $(A)$. For the experiment on $\left[{ }^{3} \mathrm{H}\right]$ thymidine incorporation, cells were plated at $5 \times 10^{4} /$ well and cultured for 24 hours. After addition of 1 $\mu \mathrm{Ci} / \mathrm{ml}$ of $\left[{ }^{3} \mathrm{H}\right]$ thymidine, the cells were cultured for 6 hours. $\left[{ }^{3} \mathrm{H}\right]$ thymidine incorporation of control cells was regarded as $100 \%$ and relative $\left[{ }^{3} \mathrm{H}\right]$ thymidine incorporation was expressed as a percentage of control $(B)$. For the colony formation assay, $1 \mathrm{ml}$ of basal layer culture medium with a final $0.5 \%$ agarose concentration was prepared in $35 \mathrm{~mm}$ culture dishes. The cells, at 2 $\times 10^{3}$ cells $/ \mathrm{ml}$, in $1 \mathrm{ml}$ of upper layer medium $(0.2 \%$ agarose) were overlaid onto the preformed basal layer. After a 10 day incubation, colonies were stained with crystal violet and colonies with more than 100 cells were counted. Cell proliferation was determined as the mean colony numbers, compared with those of control $(100 \%)(C)$. Control cells received neither treatment nor transfection (Control). Each bar represents the mean \pm standard deviation of four separate experiments. ${ }^{*} p<0.05$ vs S ODN; ${ }^{+} p<0.05$ vs $p c N-3$.

Western blot analysis for COX-2 protein in the AGS cells showed similar inhibition with AS ODN treatment or transfection of the mutated $I_{\kappa} \mathrm{B} \alpha$ gene (Fig. $5 \mathrm{~B}$ ). This led to low levels of $\mathrm{TXB}_{2}$ and 6-keto-PGF ${ }_{1 \alpha}$, metabolic products of COX-2 in the AGS cells (Fig. 6), which had relatively low levels of NF- $\kappa$ B in the nucleus (Fig. 2). From these results, we postulate that NF- $\kappa \mathrm{B}$ seems to be activated to reach nuclear levels even in resting cells, and NF- $\kappa \mathrm{B}$ mediates COX-2 expression and cell proliferation in AGS cells. Thus, inhibition of NF- $\kappa$ B activation either by suppressing translation of the NF- $\kappa$ B subunit p50 (AS ODN) or by suppressing the phosphorylation of $I_{\kappa} B \alpha$ (IW-6 and IW-10) induces low COX-2 gene expression, which results in a low rate of cell proliferation in AGS cells. 
A

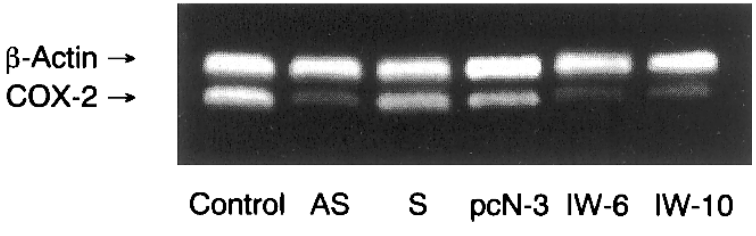

B

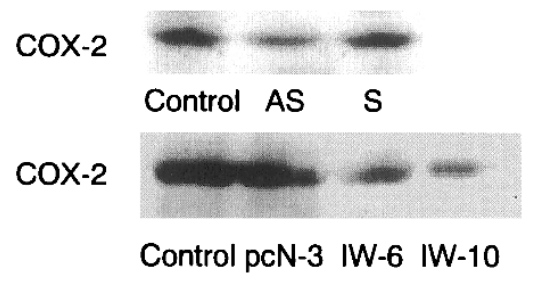

Figure 5.

Reverse transcription polymerase chain reaction (RT-PCR) and Western blot analysis for COX-2 on cells treated with ODN or transfected with the mutated $I_{\kappa} \mathrm{B} \alpha$ gene. Cells were treated with $A S$ ODN or $S$ ODN for 72 hours or transfected with control pcDNA3 vector $(p c N-3)$ or the mutated $I_{\kappa} \mathrm{B} \alpha$ gene (IW-6 and IW-10). For RT-PCR analysis, total RNA was isolated from the cells by the guanidine thiocyanate extraction method. mRNA expression of COX-2 was assessed using RT-PCR standardized by coamplifying this gene with the housekeeping gene $\beta$-actin $(A)$. For Western blot analysis, cell lysates (100 $\mu \mathrm{g}$ of protein) were subjected to $8 \%$ SDS-PAGE and transferred onto membranes. COX-2 protein was visualized with a COX-2-specific antibody $(B)$. Control cells received neither treatment nor transfection (Control).

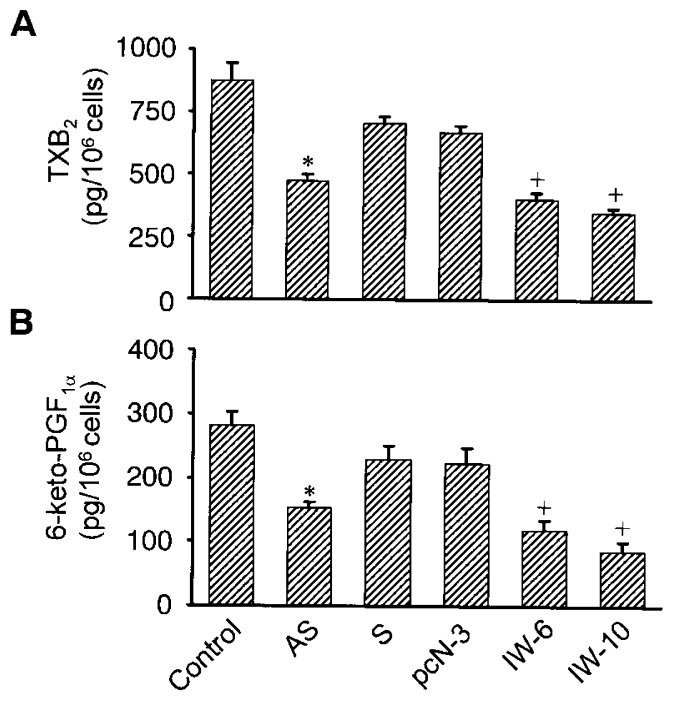

Figure 6.

Levels of thromboxane $\mathrm{B}_{2}\left(T X B_{2}\right)$ and 6-keto-prostaglandin $\mathrm{F}_{1 \alpha}\left(6-k e t o-P G F_{1 \alpha}\right)$ of the cells treated with ODN or transfected with the mutated $I_{\kappa} B \alpha$ gene. Cells were treated with $A S$ ODN or $S$ ODN for 72 hours or transfected with control pcDNA-3 vector $(p c N-3)$ or the mutated $I_{\kappa} B \alpha$ gene $(I W-6$ and $I W-10)$. The cells were plated at $5 \times 10^{4}$ cells/well and cultured for 24 hours. $\mathrm{TXB}_{2}$ and 6-keto-PGF ${ }_{1 \alpha}$ were determined in the medium by ELISA. Control cells received neither treatment nor transfection (Contro). Each bar represents the mean \pm standard deviation of four separate experiments. ${ }^{\star} p<0.05$ vs S $0 \mathrm{DN} ;{ }^{+} p<$ 0.05 vs pcN-3.

\section{Effects of COX-2 Inhibitors on Proliferation of AGS Cells}

We examined whether inhibition of COX-2 would reduce the proliferation of AGS cells (Fig. 7). Treatment of a nonspecific COX-2 inhibitor, indomethacine, resulted in a dosage-dependent suppression of cell
A
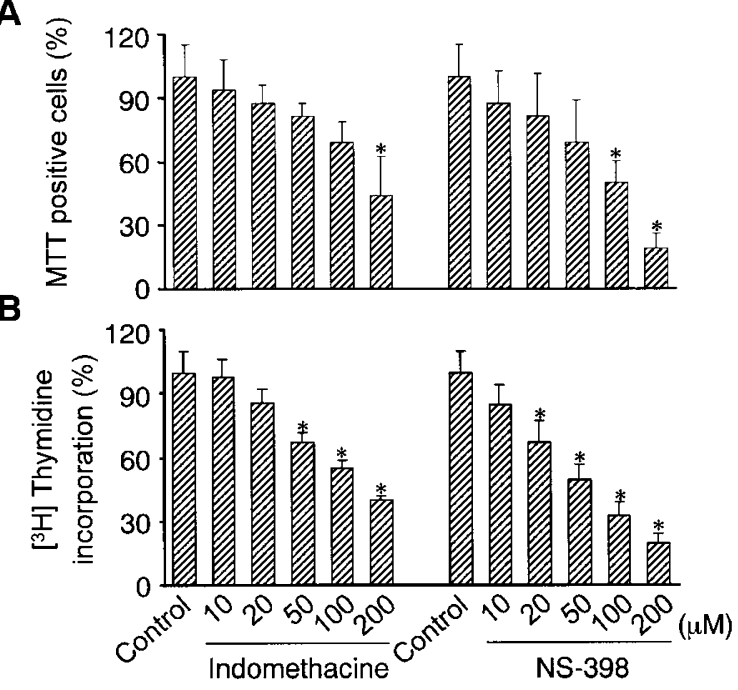

Figure 7

Effect of COX-2 inhibitors on cell proliferation of AGS cells, determined by the percentage of MTT-positive cells and thymidine incorporation. For the analysis of MTT-positive cells, $1 \times 10^{3}$ cells/well were treated with indomethacine or NS-198 for 96 hours. Viable cells were assessed by MTT assay and MTT positive cells were expressed as a percentage of control $(A)$. For $\left[{ }^{3} \mathrm{H}\right]$ thymidine incorporation, cells were plated at $5 \times 10^{4}$ cells/well and cultured for 24 hours. After addition of $1 \mu \mathrm{Ci} / \mathrm{ml}$ of $\left[{ }^{3} \mathrm{H}\right]$ thymidine, the cells were cultured for 6 hours. $\left[{ }^{3} \mathrm{H}\right]$ thymidine incorporation of control cells was regarded as $100 \%$ and relative $\left[{ }^{3} \mathrm{H}\right]$ thymidine incorporation was expressed as a percentage of control $(B)$. Each bar represents the mean \pm standard deviation of four separate experiments. ${ }^{\star} p<0.05$ vs control.

proliferation, as determined by percentage of MTTpositive cells after 96 hours in culture and $\left[{ }^{3} \mathrm{H}\right]$ thymidine incorporation after 24 hours in culture. Similar results were obtained by treatment with a specific COX-2 inhibitor, NS-398. The inhibitory effect of NS398 on cell proliferation was more potent than that of indomethacine. An approximately 50\% inhibition of cell proliferation was reached by treatment with 200 $\mu \mathrm{M}$ of indomethacine and by $100 \mu \mathrm{M}$ of NS-398. Similar inhibitory effects by indomethacine and NS398 on COX-2 activity were observed, as determined by the levels of $\mathrm{TXB}_{2}$ and 6-keto-PGF ${ }_{1 \alpha}$ in the medium after 24 hours in culture (Fig. 8). Thus, COX-2 expression may be one of the major pathways leading to cell proliferation in AGS cells.

\section{Effect of $\mathrm{PGE}_{2}$ on Proliferation of AGS Cells}

After 24 hours in culture, the effect of $\mathrm{PGE}_{2}$ treatment on cell proliferation was observed by $\left[{ }^{3} \mathrm{H}\right]$ thymidine incorporation in AGS cells that were either treated with AS ODN or transfected with the mutated $I_{\kappa} \mathrm{B} \alpha$ gene (IW-6 and IW-10) (Fig. 9). Effects were also measured by the percentage of MTT-positive cells after 96 hours of culture (Fig. 10). After 24 hours of culture, $\mathrm{PGE}_{2}$ had no effect on $\left[{ }^{3} \mathrm{H}\right]$ thymidine incorporation of control cells, cells treated with $\mathrm{S}$ ODN, or cells transfected with $\mathrm{pcN}-3$. However, $\mathrm{PGE}_{2}$ stimulated $\left[{ }^{3} \mathrm{H}\right]$ thymidine incorporation of the cells treated with AS ODN or transfected with the mutated $1 \kappa \mathrm{B} \alpha$ gene (IW- 6 and IW-10), in a dose-dependant manner. This suggests that addition of $\mathrm{PGE}_{2}$ prevented inhibition of cell 
A

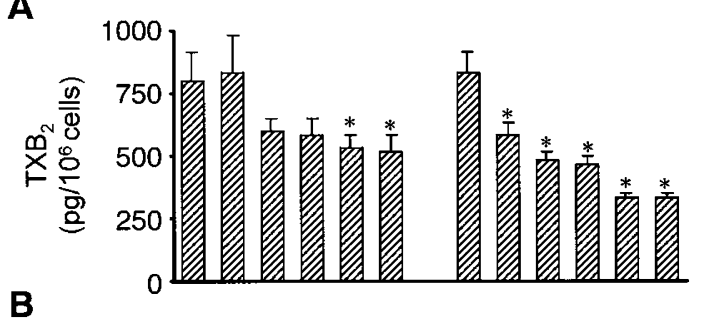

B

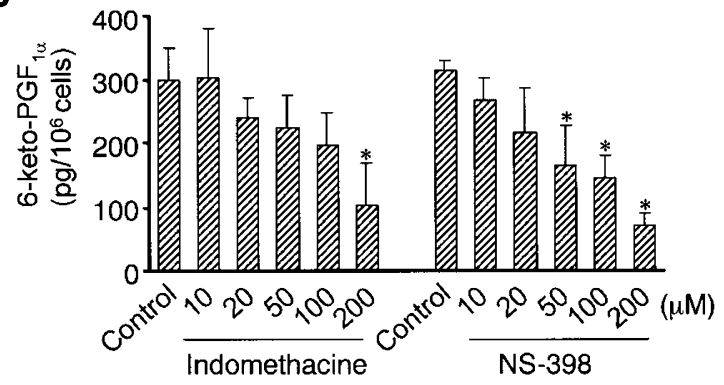

Figure 8.

Levels of TXB 2 and 6-keto-PGF $F_{1 \alpha}$ of the cells treated with COX-2 inhibitors. The cells received neither treatment nor transfection and were plated at $5 \times 10^{4}$ cells/well, treated with indomethacine or NS-398, and cultured for 24 hours. $\mathrm{TXB}_{2}$ and 6-keto-PGF $F_{1 \alpha}$ were determined in the medium by ELISA. Control cells were not treated with COX-2 inhibitors (Contro). Each bar represents the mean \pm standard deviation of four separate experiments. ${ }^{*} p<0.05$ vs corresponding control.

A

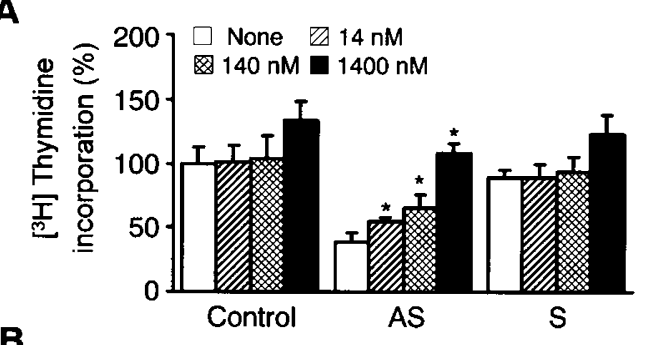

B

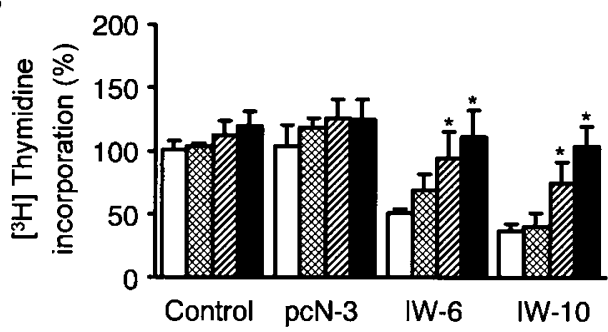

Figure 9.

Effect of prostaglandin $E_{2}\left(P_{G} E_{2}\right)$ on proliferation of AGS cells treated with ODN or transfected with the mutated $I_{\kappa} \mathrm{B} \alpha$ gene, determined by thymidine incorporation. Cells were plated at $5 \times 10^{4}$ cells/well, treated with $\mathrm{PGE}_{2}$ and cultured for 24 hours. After addition of $1 \mu \mathrm{Ci} / \mathrm{ml}$ of $\left[{ }^{3} \mathrm{H}\right]$ thymidine, the cells were cultured for 6 hours. $\left[{ }^{3} \mathrm{H}\right]$ thymidine incorporation of control cells was regarded as $100 \%$ and relative $\left[{ }^{3} \mathrm{H}\right]$ thymidine incorporation was expressed as a percentage of control. Each bar represents the mean \pm standard deviation of four separate experiments. ${ }^{*} p<0.05$ vs the corresponding none.

proliferation in cells with low levels of NF- $\kappa \mathrm{B}$ in the nucleus. The stimulatory effect of $\mathrm{PGE}_{2}$ on cell proliferation was observed in control cells, cells treated with S ODN, and in cells transfected with the control vector, as determined by the percentage of MTTpositive cells after 96 hours of culture (Fig. 10). The effect of $\mathrm{PGE}_{2}$ on cell proliferation was greater in the
A

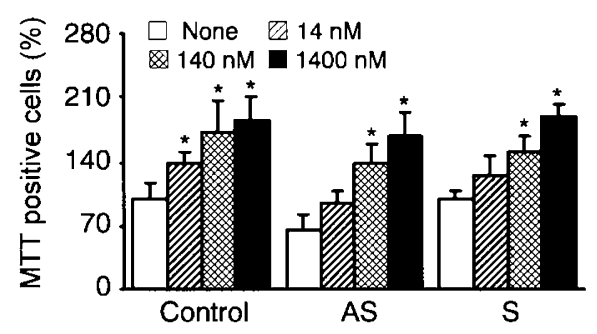

B

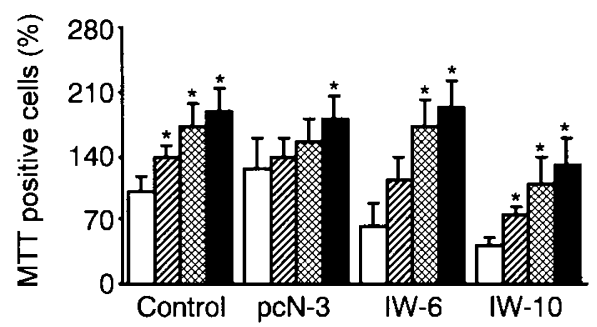

Figure 10.

Effect of $P G E_{2}$ on cell proliferation of AGS cells treated with ODN or transfected with the mutated $I_{\kappa} \mathrm{B} \alpha$ gene, determined by percentage of MTT-positive cells. $1 \times 10^{3}$ cells/well were treated with $\mathrm{PGE}_{2}$ for 96 hours. Viable cells were assessed by MTT assay and MTT-positive cells were expressed as a percentage of control. Each bar represents the mean \pm standard deviation of four separate experiments. ${ }^{*} p<0.05$ vs the corresponding none.

cells treated with AS ODN or transfected with the mutated $I_{\kappa} \mathrm{B} \alpha$ gene than in control cells, cells treated with S ODN, or cells transfected with control vector.

\section{Discussion}

Histopathologic and epidemiologic studies showed that gastric cancer may be associated with hyperproliferation of gastric cells (Kemppainen et al, 1997; Persing and Prendergast, 1999) and this hypothesis was proven in studies on Helicobacter pylori infection (Correa, 1997; Guarner et al, 1993; Lynch and Axon, 1995; Moss, 1999). Increased proliferation of gastric cells by Helicobacter pylori was inhibited by supplementation of antioxidants and NF- $\kappa \mathrm{B}$ inhibitors (Bukin et al, 1993; Sharma et al, 1995). Although there is no direct evidence, these studies suggest that NF- $\kappa$ B activation in gastric cells may be associated with hyperproliferation and gastric carcinogenesis. NF- $\kappa \mathrm{B}$ participates in cell proliferation, transformation, and tumor development (Siebenlist et al, 1994; Wulczyn et al, 1996). Several studies have demonstrated that inhibition of constitutive NF- $\kappa \mathrm{B}$ in B-cell lymphoma and breast cancer cells led to cell apoptosis, and that ectopic c-Rel expression promoted cell survival (Arsura et al, 1996; Sovak et al, 1997; Thanos and Maniatis, 1995). Furthermore, NF- $\kappa$ B activation was linked to the protection of multiple types of cells from apoptosis (Wang et al, 1996).

In the present study, we found that unstimulated gastric cancer AGS cells had constitutive NF- $\kappa B$ in the nucleus, and that inhibition of constitutive NF- $\kappa B$ suppressed cell proliferation. These data suggest that $\mathrm{NF}-\kappa \mathrm{B}$ may have an important role in human gastric cancer cell proliferation. In up to 96 hours of culture, inhibition of constitutive NF- $\kappa$ B did not induce apo- 
ptosis of AGS cells, as determined by Hoechst staining and DNA fragmentation (data not shown). This is in agreement with the report by Sawaoka et al (1998), which demonstrated that both NS-398 and indomethacine inhibited cell proliferation in gastric cancer MKN 45 cells in which COX-2 was overexpressed. However, neither NS-398 nor indomethacine induced apoptosis, as determined by DNA fragmentation. Some cancer cells, pancreatic cancer cells (Ding et al, 2000), and colorectal cancer cells (Chinery et al, 1998; Elder et al, 1997; Hara et al, 1997) showed growth inhibition and apoptosis by COX-2 inhibition. The differential effects on apoptosis by COX-2 inhibitors may be explained by different culture conditions (serum content in the medium, incubation time, etc.) and cell-type specificity.

In transformed cell lines, AS ODN to Rel A (p65) inhibited both cell proliferation and the ability of the cells to adhere to an extracellular matrix, and ablated tumor growth in mice (Higgins et al, 1993; Kitajima et al, 1992). NF- $\kappa \mathrm{B}$ is involved in the expression of adhesion molecules (Collins et al, 1995) and various enzymes including COX-2. Thus, autocrine actions of enzymes and mediators induced by NF- $\kappa \mathrm{B}$ could lock cells into permanently activated states, mimicking continuous growth-promoting signaling, and allowing easier adherence to extracellular matrix for carcinogenesis.

Of the possible target genes of NF- $\kappa \mathrm{B}$, we focused on COX-2 expression because the human and murine COX-2 gene promoters contain a regulatory DNA sequence to which NF- $\kappa$ B binds (Boolbol et al, 1996), and COX-2 expression is regulated by NF- $\kappa \mathrm{B}$ in several cell lines (Boolbol et al, 1996; Hla and Neilson, 1992). In some cancer cells, COX-2 is involved in the regulation of cell proliferation (Martinez et al, 1997; Sheng et al, 1997). In the present study, we demonstrated that NF- $\kappa \mathrm{B}$ regulated $\mathrm{COX}-2$ expression and prostaglandin synthesis in AGS cells, as determined by the levels of $\mathrm{TXB}_{2}$ and 6-keto-PGF ${ }_{1 \alpha}$ in the medium. COX-2 expression was necessary for mitogenor endotoxin-induced production of prostaglandins in murine fibroblasts and macrophages, whereas the COX-1 present in these cells cannot utilize arachidonic acid released in response to mitogen or endotoxin stimulation (Shimakura and Boland, 1992). Consequently, prostaglandins induced by COX-2 may exert different effects from those induced by COX-1. COX-2 inhibitors suppressed prostaglandins and cell proliferation in several gastrointestinal cancer cells (Nishikawa et al, 1997), pancreatic cancer cells (Ding et al, 2000) and colorectal cancer cell lines (Elder et al, 1997; Hara et al, 1997). This suggests that prostaglandins induced by COX-2, not by COX-1, affect cell proliferation in those cells. $\mathrm{PGE}_{2}$ production by COX2-stimulated cell proliferation in some cancer cells (Battu et al, 1998; Higashi et al, 2000; Molina et al, 1999; Sheng et al, 1997) was confirmed in present study. We used nonspecific (indomethacine) and specific (NS-398) COX-2 inhibitors to suppress COX-2 expression and demonstrated that NS-398 was more potent than indomethacine in inhibiting cell prolifera- tion and COX-2 activity, as determined by the levels of $\mathrm{TXB}_{2}$ and 6-keto-PGF ${ }_{1 \alpha}$. NS-398 has been as effective as AS ODN for COX-2 in lowering prostaglandin production and cell proliferation in gastric epithelial cells (Sawaoka et al, 1999). Therefore, we could postulate that suppression of COX-2 expression by NS398 might effectively inhibit cell proliferation, similar to the effect of AS ODN for COX-2. Although we did not use AS ODN for COX-2 in present study, the results obtained from NS-398 demonstrate that cell proliferation is related to COX-2 expression in AGS cells. Clearly, the present study shows that NF- $\kappa \mathrm{B}$ regulates COX-2 expression, and that inhibition of COX-2 suppresses proliferation of gastric cancer AGS cells.

Although the present results demonstrate that $\mathrm{NF}-\kappa \mathrm{B}$ and $\mathrm{COX}-2$ are involved in gastric cancer cell proliferation, the role of $\mathrm{NF}-\kappa \mathrm{B}$ and $\mathrm{COX}-2$ in gastric carcinogenesis remained to be determined. The members of the NF- $\kappa \mathrm{B}$ family have been identified as protooncogenes (Wulczyn et al, 1996). Several investigators indicated that NF- $\kappa$ B was aberrantly activated in B-cell lymphoma, in human breast cancer, and in rat mammary tumors from the aromatic hydrocarboninduced model of breast cancer. Antioxidants such as pentoxifylline and $\mathrm{N}$-acetyl cysteine, which suppress $\mathrm{NF}-\kappa \mathrm{B}$ activation, are in clinical use for treating some cancers (Biswas et al, 1993; Chinery et al, 1998). Ristimaki and colleagues (1997) reported that mRNA expression of COX-2 in human gastric carcinoma tissue was significantly higher than that in noncancerous adjacent tissue. Additionally, current users of aspirin, a nonspecific COX-2 inhibitor, had a decreased risk for gastric cancer in a case control study (Farrow et al, 1998).

The present study demonstrates that inhibition of constitutive NF- $\kappa \mathrm{B}$ results in inhibition of COX-2 expression and proliferation of gastric cancer cells. Thus, NF- $\kappa \mathrm{B}$ may have a novel role in gastric cancer cell proliferation via COX-2 expression. NF- $\kappa \mathrm{B}$ inhibitors and COX-2 inhibitors may be potentially useful for the treatment of gastric cancer. However, further study should be performed to elucidate the precise role of constitutive NF- $\kappa \mathrm{B}$ and $\mathrm{COX}-2$ in initiation and promotion of gastric carcinogenesis.

\section{Materials and Methods}

\section{Cell Culture}

Human gastric cancer AGS cells (gastric adenocarcinoma, ATCC CRL 1739) were obtained from the American Type Culture Collection (Rockville, Maryland) and cultured in RPMI-1640 medium ( $\mathrm{pH} 7.4)$ (Sigma, St. Louis, Missouri), supplemented with $10 \%$ fetal bovine serum (GIBCO BRL, Grand Island, New York) and antibiotics (100 U/ml of penicillin and 100 $\mu \mathrm{g} / \mathrm{ml}$ of streptomycin).

\section{ODN Preparation}

Single-stranded ODN were produced commercially (GIBCO BRL). Phosphothioate-modified ODN were used to reduce intracellular nuclease digestion. AS 
ODN and S ODN targeted the ATG start codon of the p50 mRNA. The sequence of the p50 AS ODN was $5^{\prime}$ GGA TCA TCT TCT GCC ATT CTG 3'. The sequence of p50 S ODN was 5' CAG AAT GGC AGA AGA TGA TCC 3'.

\section{Treatment with ODN Using Cationic Liposome}

AGS cells were treated with ODN using a cationic liposome, a commercially available transfection reagent, DOTAP (N-[1-(2, 3-dioleoyloxy) propyl]-N, N,Ntrimethyl ammonium methylsulfate) (BoehringerMannheim, Mannheim, Germany), to improve stability and intracellular delivery of ODN (Lappalainen et al, 1994). When DOTAP was used, the appropriate amount of ODN was incubated with DOTAP $(15 \mu \mathrm{l} / \mathrm{ml})$ and a final concentration of the ODN of $0.5 \mu \mathrm{m}$ at $37^{\circ} \mathrm{C}$ for 15 minutes. The mixture was added directly to the cells, plated at $2 \times 10^{5}$ cells $/ \mathrm{ml}$ in 12 -well plates, and incubated for 55 hours. Cells were trypsinized and plated again at a density of $5 \times 10^{5}$ cells $/ \mathrm{ml}$ in 6 -well plates. A final concentration of $0.5 \mu \mathrm{M}$ of ODN was added to the cells and incubated for an additional 17 hours. Western blot analysis for p50 (Fig. 1A) and EMSA for NF- $\kappa \mathrm{B}$ (Fig. 2A) were performed on the nuclear extract of the cells treated with AS ODN or $S$ ODN and control cells, which received no treatment.

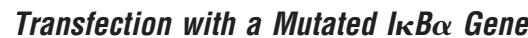

As a mutated $I_{\kappa} \mathrm{B} \alpha$ gene, the MAD-3 double point mutant (substitution of two serine residues by alanine residues at positions 32 and 36 ) construct was prepared as described previously (Traenckner et al, 1995). The control vector pcDNA3 (InVitrogen, Carlsbad, California) was transfected into the cells instead of the mutated $\mathrm{I}_{\kappa} \mathrm{B} \alpha$ gene. These cells were regarded as a relative control and named pcN-3. Subconfluent AGS cells, plated in $10 \mathrm{~cm}$ culture plates, were transfected with $10 \mu \mathrm{g}$ of expression construct using DOTAP for 16 hours. After transfection, the cells were trypsinized and plated at $1 \times 10^{3}$ cells per $10 \mathrm{~cm}$ tissue culture plate. The cells were cultured in medium containing $400 \mu \mathrm{g} / \mathrm{ml}$ of G-418 (GIBCO BRL) for 15 to 17 days. Three to four resistant clones were isolated from each plate and examined for mutated $I_{\kappa} \mathrm{B} \alpha$ expression by Western blot analysis. The positive clones for mutated $I_{\kappa} \mathrm{B} \alpha$ were maintained in culture medium containing $200 \mu \mathrm{g} / \mathrm{ml}$ of G418 for more than 2 months and named IW-6 and IW-10. Western blot analysis for wild-type $I_{\kappa} \mathrm{B} \alpha$, phosphorylated $I_{\kappa} \mathrm{B} \alpha$, and mutated $\mathrm{I}_{\kappa} \mathrm{B} \alpha$ (Fig. 1A) and EMSA for NF- $\kappa \mathrm{B}$ (Fig. 2A) were performed on cells transfected with the control vector (pcDNA3) or the mutated $I_{\kappa} \mathrm{B} \alpha$ gene and on control cells that received no transfection.

\section{Western Blot Analysis for P50, ІкBa, and COX-2}

Cells treated with ODN or transfected with the mutated $\mathrm{I}_{\kappa} \mathrm{B} \alpha$ gene were homogenized in Tris- $\mathrm{HCl}(\mathrm{pH}$ 7.4) buffer containing $0.5 \%$ Triton $\mathrm{X}-100$ and a protease inhibitor cocktail (Boehringer-Mannheim, Indianapolis, Indiana) for determination of $I_{\kappa} \mathrm{B} \alpha$ and COX-2.
Nuclear extract was prepared as described in the next paragraph for the determination of $\mathrm{p} 50$. The protein concentration of each sample was measured by the method used in Bradford (1976). One hundred micrograms of cellular protein (for $1 \kappa \mathrm{B} \alpha$ and COX-2) or $20 \mu \mathrm{g}$ of nuclear protein (for p50) was loaded per lane, separated by $8 \%$ SDS-polyacrylamide gel electrophoresis under reducing conditions, and transferred onto nitrocellulose membranes (Amersham Inc., Arlington Heights, Illinois) by electroblotting. The transfer of protein and equality of loading in all lanes was verified using reversible staining with Ponceau S. Membranes were blocked using 5\% nonfat dry milk. Wild-type $I_{\kappa} \mathrm{B} \alpha$, phosphorylated $\mathrm{I}_{\kappa} \mathrm{B} \alpha$, mutant-type $I_{\kappa} \mathrm{B} \alpha, \mathrm{COX}-2$ protein, and p50 protein were detected by incubation of the blots with the corresponding monoclonal antibodies (Cayman Chemical, Ann Arbor, Michigan) at a dilution of 1:1000 overnight at $4^{\circ} \mathrm{C}$. Blots were incubated with goat anti-rabbit secondary antibodies conjugated to horseradish peroxidase and enhanced chemiluminescence (Amersham) using exposure to BioMax MR film (Kodak, Rochester, New York) was determined.

\section{Extraction of Nuclei}

The cells, treated with ODN or transfected with the mutated $I_{\kappa} \mathrm{B} \alpha$ gene, were rinsed with ice-cold phosphate buffered saline (PBS), harvested by scraping into PBS, and pelleted by centrifugation at $1500 \times \mathrm{g}$ for 5 minutes. The cells were lysed in buffer containing $10 \mathrm{~mm}$ Hepes, $10 \mathrm{~mm} \mathrm{KCl,} 0.1 \mathrm{~mm}$ ethylenediaminetetraacetic acid (EDTA), $1.5 \mathrm{~mm} \mathrm{MgCl}_{2}, 0.2 \%$ Nonidet $\mathrm{P}-40,1 \mathrm{~mm}$ dithiothreitol (DTT), and $0.5 \mathrm{~mm}$ phenylmethylsulfonylfluoride (PMSF). The nuclear pellet was resuspended on ice in nuclear extraction buffer containing $20 \mathrm{~mm}$ Hepes, $420 \mathrm{~mm} \mathrm{NaCl}, 0.1 \mathrm{~mm}$ EDTA, 1.5 $\mathrm{mm} \mathrm{MgCl}_{2}, 25 \%$ glycerol, $1 \mathrm{~mm}$ DTT, and $0.5 \mathrm{~mm}$ PMSF (Li et al, 1997), and the nuclear protein concentration was determined by the method used in Bradford (1976).

\section{EMSA}

The NF- $\kappa$ B gel shift oligonucleotide, 5'AGT TGA GGG GAC TIT CCC AGG C-3' (Promega Corporation, Madison, Wisconsin) was labeled with $\left[{ }^{32} \mathrm{P}\right]$ dATP (Amersham) using a T4 polynucleotide kinase (GIBCO BRL). An end-labeled probe was purified from unincorporated $\left[{ }^{32} \mathrm{P}\right]$ dATP using a Bio-Rad purification column (Bio-Rad Laboratories, Hercules, California) and recovered in Tris-EDTA buffer. Nuclear extracts $(1 \mu \mathrm{g})$ were preincubated in buffer containing $12 \%$ glycerol; 12 mм Hepes, $\mathrm{pH} 7.9 ; 4$ mм Tris- $\mathrm{HCl}, \mathrm{pH} 7.9 ; 1$ mм EDTA; $1 \mathrm{~mm}$ DTT; 25 mм KCl; 5 mm $\mathrm{MgCl}_{2} ; 0.04 \mu / \mathrm{ml}$ of poly[d(I-C)] (Boehringer Mannheim); 0.4 mM PMSF; and Tris-EDTA buffer. The labeled probe was added and samples were incubated on ice for 10 minutes. Samples were subjected to electrophoresis at room temperature on a nondenaturing $5 \%$ acrylamide gel at $30 \mathrm{~mA}$ using $0.5 \mathrm{x}$ Tris borate EDTA buffer. The gels were dried at $80^{\circ} \mathrm{C}$ for 1 hour and exposed to radiog- 
raphy film for 6 to 18 hours at $-70^{\circ} \mathrm{C}$ with intensifying screens (Li et al, 1997).

\section{RT-PCR Analysis for COX-2}

Gene expression of COX-2 mRNA was assessed using RT-PCR standardized by coamplifying COX-2 with the housekeeping gene $\beta$-actin, which served as an internal control. Total RNA was isolated from the cells, treated with ODN, or transfected with the mutated $I_{\kappa} \mathrm{B} \alpha$ gene by the guanidine thiocyanate extraction method (Chomczynski and Sacchi, 1987). Total RNA was reverse transcribed into cDNA and used for PCR with human specific primers for COX-2 and $\beta$-actin. Sequences of COX-2 primers were $5^{\prime}-$ TTCAAATGAGATTGTGGGAAAATTGCT-3' (forward primer) and 5'-AGATCATCTCTGCCTGAGTATCTT-3' (reverse primer), giving a 305 bp PCR product (Hla and Neilson, 1992). For $\beta$-actin, the forward primer was 5'-ACCAACTGGGACGACATGGAG-3' and the reverse primer was 5'-GTGAGGATCTTCATGAGGTAGTC-3', giving a 349 bp PCR product (Nakajima-lijima et al, 1985). Briefly, the PCR was amplified by 32 repeat denaturation cycles at $95^{\circ} \mathrm{C}$ for 30 seconds, annealing at $60^{\circ} \mathrm{C}$ for 30 seconds, and extension at $72^{\circ} \mathrm{C}$ for 30 seconds. During the first cycle, the $95^{\circ} \mathrm{C}$ step was extended to 2 minutes, and on the final cycle the $72^{\circ} \mathrm{C}$ step was extended to 5 minutes. PCR products were separated on $1.5 \%$ agarose gels containing $0.5 \mu \mathrm{g} / \mathrm{ml}$ of ethidium bromide and visualized by UV transillumination.

\section{Determination of Cell Proliferation}

Proliferation of the cells treated with ODN or transfected with the mutated $I_{\kappa} \mathrm{B} \alpha$ gene was determined by four methods: trypan blue exclusion, MTT assay, $\left[{ }^{3} \mathrm{H}\right]$ thymidine incorporation, and colony formation. Control cells received neither treatment nor transfection. For the trypan blue exclusion test, the cells were plated at $2 \times 10^{4}$ cells/well in a 24-well culture plate and incubated for 24, 48, 72, and 96 hours. Cell number was counted on a hemocytometer using $0.2 \%$ trypan blue. For the MTT assay, the cells $\left(1 \times 10^{3}\right.$ cells/well) were plated into a 96 -well culture plate and cultured for 96 hours. MTT $(0.5 \mathrm{mg} / \mathrm{ml})$ was added and the reaction mixture was incubated for 4 hours at $37^{\circ} \mathrm{C}$. Cellular formazan was extracted with acid propan-2-ol and the absorbance was measured with a dual wavelength automatic plate reader at $570 \mathrm{~nm} / 630$ $\mathrm{nm}$ (Yang et al, 1998). Viable cell number was expressed as the percentage of MTT-positive cells; control cells were regarded as $100 \%$. For $\left[{ }^{3} \mathrm{H}\right]$ thymidine incorporation, the cells were plated at $5 \times 10^{4}$ cells/well in a 24-well culture plate. After 24 hours of incubation, $1 \mu \mathrm{Ci} / \mathrm{ml}$ of $\left[{ }^{3} \mathrm{H}\right]$ thymidine (Amersham) was added to the cells, which were then incubated for 6 hours. After washing with PBS, the cells were incubated with 10\% trichloroacetic acid for 30 minutes. The cells were washed, incubated with a solution containing $0.3 \mathrm{M} \mathrm{NaOH}$ and $1 \%$ sodium dodecyl sulfate for 1 hour, and the radioactivity of the cell lysate was counted as cpm by a liquid scintillation counter. $\left[{ }^{3} \mathrm{H}\right]$ thymidine incorporation, reflecting DNA synthesis (Chinery et al, 1998), of control cells was regarded as $100 \%$ and relative $\left[{ }^{3} \mathrm{H}\right]$ thymidine incorporation was expressed as a percentage of the control value. For colony formation, a soft agar assay was performed using a double-layer agar system (Sevignani et al, 1998). One milliliter of basal layer culture medium (RPMI medium with 10\% FBS) with a final $0.5 \%$ agarose (GIBCO-BRL) concentration was prepared in 35-mm culture dishes. The cells, at $2 \times 10^{3}$ cells $/ \mathrm{ml}$, in $1 \mathrm{ml}$ of upper layer medium (0.2\% agarose) were overlaid onto the preformed basal layer. After 10 days of incubation, colonies were stained with crystal violet and colonies with greater than 100 cells were counted. Cell proliferation was determined as mean colony numbers, compared with those of control (100\%). In addition, control cells that had neither treatment with ODN nor transfection with the mutated $I_{\kappa} \mathrm{B} \alpha$ gene, were treated with 10, 20, 50, 100, and 200 $\mu \mathrm{M}$ of COX-2 inhibitors, such as indomethacine (Sigma) and NS-398 (Alexis Biochemicals, San Diego,

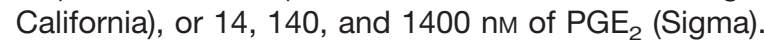
The drug concentrations used in the present study were adapted from previous studies for COX-2 inhibitors (Ding et al, 2000; Elder et al, 1997; Hara et al, 1997) and $\mathrm{PGE}_{2}$ (Millet et al, 1998; Monteleone et al, 1999; Yamamoto et al, 1999). Cell proliferation was determined by MTT assay and $\left[{ }^{3} \mathrm{H}\right]$ thymidine incorporation as described above.

\section{Determination of $\mathrm{TXB}_{2}$ and 6-Keto-PGF}

The cells, treated with ODN or transfected with the mutated $I_{\kappa} \mathrm{B} \alpha$ gene, were plated at $5 \times 10^{4}$ cells/well in 24-well culture plates and cultured for 24 hours. Levels of $\mathrm{TXB}_{2}$ and 6-keto-PGF ${ }_{1 \alpha}$ were determined in the medium by ELISA kits (R\&D System, Minneapolis, Minnesota). Additionally, control cells that received neither treatment with ODN nor transfection with the mutated $\mathrm{I}_{\kappa} \mathrm{B} \alpha$ gene, were treated with 10, 20, 50, 100, and $200 \mu \mathrm{M}$ of COX-2 inhibitors and levels of $\mathrm{TXB}_{2}$ and 6-keto-PGF ${ }_{1 \alpha}$ were determined in the medium. Purified human recombinant $\mathrm{TXB}_{2}$ and 6-keto-PGF ${ }_{1 \alpha}$ were used as standards. Levels of $\mathrm{TXB}_{2}$ and 6-keto-PGF ${ }_{1 \alpha}$ were expressed as picograms per $10^{6}$ cells.

\section{Statistical Analysis}

Results are expressed as means \pm standard deviation of four separate experiments. ANOVA followed by Newman-Keul's test was used for statistical analysis (Zar, 1984). $p<0.05$ was regarded as statistically significant.

\section{References}

Arsura M, Wu M, and Sonenshein GC (1996). TGF- $\beta 1$ inhibits NF- $\kappa$ B/Rel activity inducing apoptosis of B cells: Transcriptional activation of $I_{\kappa} \mathrm{B} \alpha$. Immunity 5:31-40.

Baeuerle PA and Baltimore D (1996). NF $-\kappa B$ : Ten years after. Cell 87:13-20. 
Baeuerle PA and Henkel T (1994). Function and activation of $\mathrm{NF}-\kappa \mathrm{B}$ in the immune system. Annu Rev Immunol 12:141179.

Barnes PJ and Karin M (1997). Nuclear factor- $\kappa$ B, a pivotal transcription factor in chronic inflammatory diseases. N Engl J Med 336:1066-1071.

Battu S, Chable-Rabinovitch H, Rigaud M, and Beneytout JL (1998). Cyclooxygenase-2 expression in human adenocarcinoma cell line HT29. Anticancer Res 18:2397-2403.

Beg AA and Baldwin AS Jr (1993). The I kappa B proteins: Multifunctional regulators of Rel/NF-kappa B transcription factors. Genes Dev 7:1564-1570.

Bhuyan BK, Adams EG, Badiner GJ, Li LH, and Barden K (1986). Cell cycle effects of prostaglandins A1, A2, and D2 in human and murine melanoma cells in culture. Cancer Res 46:1688-1693

Biswas DK, Dezube BJ, Ahlers CM, and Pardee AB (1993). Pentoxifylline inhibits HIV-1 LTR-driven gene expression by blocking NF- $\kappa$ B action. J Acquir Immune Defic Syndr 6:778786.

Boolbol SK, Dannenberg AJ, Chadburn A, Martucci C, Guo XJ, Ramonetti JT, Abreu-Goris M, Newmark HL, Lipkin ML, De Cosse JJ, and Bertagnolli MM (1996). Cyclooxygenase-2 overexpression and tumor formation are blocked by sulindac in a murine model of familial adenomatous polyposis. Cancer Res 56:2556-2560.

Bradford MM (1976). A rapid and sensitive method for the quantitation of microgram quantities of protein utilizing the principle of protein-dye binding. Anal Biochem 72:248-254.

Brown DA, Kang S, Gryaznov SM, DeDionisio L, Heidenreich O, Sullivan S, Xu X, and Nerenberg MI (1994). Effect of phosphorothioate modification of oligodeoxynucleotides on specific protein binding. J Biol Chem 169:26801-26805.

Brown K, Gersberger S, Carlson L, Franzoso G, and Siebenlist $U$ (1995). Control of $I_{\kappa} \mathrm{B} \alpha$ proteolysis by site-specific, signal-induced phosphorylation. Science 267:1485-1488.

Bukin YV, Zaridze DG, Draudin-Krylenki VA, Orlov EN, Sigacheva NA, Dawei F, Kurtzman MY, Schlenskaya IN, Gorbacheva ON, and Nechipa AM (1993). Effect of $\beta$-carotene supplementation on the activity of ornithine decarboxylase (ODC) in stomach mucosa of patients with atrophic gastritis. Eur J Cancer Prev 2:61-68.

Cai Z, Korner M, Tarantino N, and Chouaib S (1997). I $\mathrm{B} \alpha$ overexpression in human breast carcinoma MCF7 cells inhibits nuclear factor- $\kappa \mathrm{B}$ activation but not tumor necrosis factor- $\alpha$-induced apoptosis. J Biol Chem 272:96-101.

Chinery R, Beauchamp RD, Shyr Y, Kirkland SC, Coffey RJ, and Morrow JD (1998). Antioxidants reduce cyclooxygenase-2 expression, prostaglandin production, and proliferation in colorectal cancer cells. Cancer Res 58:2323-2327.

Chinery R, Coffey RJ, Graves-Deal R, Kirkland SC, Sanchez SC, Zackert WE, Oates JA, and Morrow JD (1999). Prostaglandin $\mathrm{J}_{2}$ and 15-deoxy-delta 12,14-prostaglandin $\mathrm{J}_{2}$ induce proliferation of cyclooxygenase-depleted colorectal cancer cells. Cancer Res 59:2739-2746.

Chomczynski P and Sacchi N (1987). Single-step method of RNA isolation by acid guanidine isothiocyanate-phenolchloroform extraction. Anal Biochem 162:156-159.
Collins T, Read MA, Neish AS, Whitley MZ, Thanos D, and Maniatis T (1995). Transcriptional regulation of endothelial cell adhesion molecules: NF- $\kappa$ B and cytokine-inducible enhancers. FASEB J 9:899-909.

Correa P (1997). Helicobacter pylori as a pathogen and carcinogen. J Physiol Pharmacol 48(Suppl 4):19-24.

Crooke ST (1992). Therapeutic applications of oligonucleotides. Annu Rev Pharmacol Toxicol 32:329-376.

Ding XZ, Tong WG, and Adrian TE (2000). Blockade of cyclooxygenase-2 inhibits proliferation and induces apoptosis in human pancreatic cancer cells. Anticancer Res 20: 2625-2631.

Elder DJ, Halton DE, Hague A, and Paraskeva C (1997). Induction of apoptotic cell death in human colorectal carcinoma cell lines by a cyclooxygenase-2 (COX-2)-selective nonsteroidal anti-inflammatory drug: Independence from COX-2 protein expression. Clin Cancer Res 3:1679-1683.

Farrow DC, Vaughan TL, Hansten PD, Stanford JL, Risch HA, Gammon MD, Chow WH, Dubrow R, Ahsan H, Mayne ST, Schoenberg JB, West AB, Rotterdam H, Fraumeni JF Jr, and Blot WJ (1998). Use of aspirin and other nonsteroidal antiinflammatory drugs and risk of esophageal and gastric cancer. Cancer Epidemiol Biomarkers Prev 7:97-102.

Gallois C, Habib A, Tao J, Moulin S, Maclouf J, Mallat A, and Lotersztajn S (1998). Role of NF- $\kappa$ B in the antiproliferative effect of endothelin-1 and tumor necrosis factor-alpha in human hepatic stellate cells. Involvement of cyclooxygenase-2. J Biol Chem 273:23183-23190.

Guarner J, Mohar A, Parsonnet J, and Halperin D (1993). The association of Helicobacter pylori and gastric cancer and preneoplastic gastric lesions in Chiapas, Mexico. Cancer 71:297-301.

Hara A, Yoshimi N, Nia M, Ino N, and Mori H (1997). Apoptosis induced by NS-398, a selective cyclooxygenase-2 inhibitor, in human colorectal cancer cell lines. Jpn J Cancer Res 88:600-604.

Haskill S, Beg AA, Tompkins SM, Morris JS, Yurochko AD, Sampson-Johannes A, Mondal K, Ralph P, and Baldwin AS Jr (1991). Characterization of an immediate-early gene induced in adherent monocytes that encodes I kappa B-like activity. Cell 65:1281-1289.

Hida T, Leyton J, Makheja AN, Ben-Av P, Hla T, Martinez A, Mulshine J, Malkani S, Chung P, and Moody TW (1998). Non-small cell lung cancer cyclooxygenase activity and proliferation are inhibited by non-steroidal anti-inflammatory drugs. Anticancer Res 18:775-782.

Higashi Y, Kanekura T, and Kanzaki T (2000). Enhanced expression of cyclooxygenase (COX)-2 in human skin epidermal cancer cells: Evidence for growth suppression by inhibiting COX-2 expression. Int $\mathrm{J}$ cancer 86:667-671.

Higgins KA, Perez JR, Coleman TA, Dorshkind K, McComas WA, Sarmiento UM, Rosen CA, and Narayanan R (1993). Antisense inhibition of the p65 subunit of NF- $\kappa$ B blocks tumorigenicity and causes tumor regression. Proc Natl Acad Sci USA 90:9901-9905.

Hla T and Neilson KO (1992). Human cyclooxygenase-2 cDNA. Proc Natl Acad Sci USA 89:7384-7388.

Jobin C, Panja A, Hellerbrand C, limuro Y, Didonato J, Brenner DA, and Sartor RB (1998). Inhibition of proinflammatory molecule production by adenovirus-mediated expres- 
sion of a nuclear factor $\kappa \mathrm{B}$ super-repressor in human intestinal epithelial cells. J Immunol 160:410-418.

Keates S, Hitti YS, Upton M, and Kelly CP (1997). Helicobacter pylori infection activates NF- $\kappa \mathrm{B}$ in gastric epithelial cells. Gastroenterology 113:1099-1109.

Kemppainen H, Raiha I, and Sourander L (1997). Clinical presentation of peptic ulcer in the elderly. Gerontology 43: 283-288.

Kim H, Seo JY, and Kim KH (1999). Effects of mannitol and dimethylthiourea on Helicobacter pylori-induced IL-8 production in gastric epithelial cells. Pharmacology 59:201-211.

Kim H, Seo JY, and Kim KH (2000). Inhibition of lipid peroxidation, NF- $\kappa \mathrm{B}$ activation and IL- 8 production by rebamipide in Helicobacter pylori-stimulated gastric epithelial cells. Dig Dis Sci 45:621-628.

Kitajima I, Shinohara T, Bilakovics J, Brown DA, Xu X, and Nerenberg M (1992). Ablation of transplanted HTLV-I Taxtransformed tumors in mice by antisense inhibition of NF- $\kappa$ B. Science 258:1792-1795.

Kojima M, Morisaki T, Izuhara K, Uchiyama A, Matsunari Y, Katano M, and Tanaka M (2000). Lipopolysaccharide increases cyclooxygenase-2 expression in a colon carcinoma cell line through nuclear factor- $\kappa \mathrm{B}$ activation. Oncogene 19:1225-1231.

Lappalainen K, Urtti A, Solderling E, Jaaskelainen I, Syrjanen K, and Syrjanen S (1994). Cationic liposomes improve stability and intracellular delivery of antisense oligonucleotides into CaSki cells. Biochem Biophys Acta 1196:201-208.

Le Bail O, Schmidt-Ullrich R, and Israel A (1993). Promoter analysis of the gene encoding the $I_{\kappa} \mathrm{B} / \mathrm{MAD}-3$ inhibitor of $\mathrm{NF}-\kappa \mathrm{B}$ : Positive regulation by members of the Rel/NF- $\kappa \mathrm{B}$ family. EMBO J 12:5043-5048.

Li JJ, Westergaard C, Ghosh P, and Colburn NH (1997). Inhibitors of both nuclear factor- $\kappa \mathrm{B}$ and activator protein-1 activation block the neoplastic transformation response. Cancer Res 57:3569-3576.

Liou HC and Baltimore D (1993). Regulation of the NF- $\kappa$ B/rel transcription factor and $1 \kappa B$ inhibitor system. Curr Opin Cell Biol 5:477-487.

Lynch DAF and Axon ATR (1995). Helicobacter pylori, gastric cancer and gastric epithelial kinetics: A review. Eur J Gastroenterol Hepatol 7(Suppl 1):S17-S23.

Martinez J, Sanchez T, and Moreno JJ (1997). Role of prostaglandin $\mathrm{H}$ synthase-2-mediated conversion of arachidonic acid in controlling 3T6 fibroblast growth. Am J Physiol 273:C1466-C1471.

Millet I, McCarthy TL, and Vignery A (1998). Regulation of interleukin- 6 production by prostaglandin $E_{2}$ in fetal rat osteoblasts: Role of protein kinase A signaling pathway. $\mathrm{J}$ Bone Miner Res 13:1092-1100.

Milligam JF, Matteucci MD, and Martin JC (1993). Current concepts in antisense drug design. J Med Chem 36:19271937.

Molina MA, Sitja-Arnau M, Lemoine MG, Frazier ML, and Sinicrope FA (1999). Increased cyclooxygenase-2 expression in human pancreatic carcinomas and cell lines: Growth inhibition by nonsteroidal anti-inflammatory drugs. Cancer Res 59:4356-4362.

Monteleone G, Parrello T, Monteleone I, Tammaro S, Luzza $F$, and Pallone $F$ (1999). Interferon-gamma and prostaglandin
$\mathrm{E}_{2}$ regulate differently $\mathrm{IL}-12$ production in human intestinal lamina propria mononuclear cells. Clin Exp Immunol 117: 469-475.

Moss SF (1999). The carcinogenic effect of Helicobacter pylori on the gastric epithelial cell. J Physiol Pharmacol 50:847-856.

Nakajima-lijima S, Hamada H, Reddy $\mathrm{P}$, and Kakunaga $\mathrm{T}$ (1985). Molecular structure of the human cytoplasmic $\beta$-actin gene: Interspecies homology of sequences in the introns. Proc Natl Acad Sci USA 82:6133-6137.

Nishikawa A, Kase Y, Hayakawa T, Yanagisawa T, Kanno J, and Hayashi $Y$ (1997). Enhancement of cell proliferation and prostaglandin biosynthesis by 1,8-dihydroxyanthraquinone in the rat large intestine. Carcinogenesis 18:1259-1263.

O'Neil G and Hutchinson AF (1993). Expression of mRNA for cyclooxygenase-1 and cyclooxygenase-2 in human tissues. FEBS Lett 330:156-160.

Persing DH and Prendergast FG (1999). Infection, immunity, and cancer. Arch Pathol Lab Med 123:1015-1022.

Plummer SM, Hall M, and Faux SP (1995). Oxidation and genotoxicity of fecapentaene- 12 are potentiated by prostaglandin H synthase. Carcinogenesis 16:1023-1028.

Ristimaki A, Honkanen N, Jankala H, Sipponen P, and Harkonen M (1997). Expression of cyclooxygenase-2 in human gastric carcinoma. Cancer Res 57:1276-1280.

Sawaoka H, Kawano S, Tsuji S, Tsuji M, Murata H, and Hori $M$ (1998). Effects of NSAIDs on proliferation of gastric cancer cells in vitro: Possible implication of cyclooxygenase-2 in cancer development. J Clin Gastroenterol 27(Suppl 1):S47S52.

Sawaoka H, Tsuji S, Tsujii M, Gunawan ES, Kawai N, Sasaki Y, Hori M, and Kawano S (1999). Involvement of cyclooxygenase-2 in proliferation and morphogenesis induced by transforming growth factor alpha in gastric epithelial cells. Prostaglandins Leukot Essent Fatty Acids 61:315322.

Seibert K, Masferrer J, Zhang Y, Gregory S, Olson G, Hauser S, Leahy K, Perkins W, and Isakson P (1995). Mediation of inflammation by COX-2. Agents Actions Suppl 46:41-50.

Seibert K, Zhang Y, and Leahy K (1994). Pharmacological and biochemical demonstration of the role of cyclooxygenase-2 in inflammation and pain. Proc Natl Acad Sci USA 91:12013-12017.

Sevignani C, Wlodarski P, Kirillova J, Mercer WE, Danielson KG, lozzo RV, and Calabretta B (1998). Tumorigenic conversion of p53-deficient colon epithelial cells by an activated K-ras gene. J Clin Invest 101:1572-1580.

Sharma S, Kerr LK, Tummuru MK, and Blaser MJ (1995). Cag $\mathrm{ABC}^{+}$cytotoxin $^{+}$Helicobacter pylori strains induce enhanced activation of transcription factor $\mathrm{NF}-\kappa \mathrm{B}$ in gastric epithelial cells (Abstract). J Leukoc Biol 28(Suppl):A134.

Sheng GG, Shao J, Sheng H, Hooton EB, Isakson PC, Morrow JD, Coffey RJ Jr, DuBois, RN, and Beauchamp RD (1997). A selective cyclooxygenase-2 inhibitor suppresses the growth of $\mathrm{H}$-ras-transformed rat intestinal epithelial cells. Gastroenterology 113:1883-1891.

Shimakura S and Boland CR (1992). Eicosanoid production by the human gastric cancer cell line AGS and its relation to cell growth. Cancer Res 52:1744-1749. 
Siebenlist U, Franzoso G, and Brown K (1994). Structure, regulation, and function of NF- $\kappa$ B. Annu Rev Cell Biol 10: 405-455.

Sovak MA, Bellas RE, Kim DW, Zanieski GJ, Rogers AE, Traish AM, and Sonenshein GE (1997). Aberrant nuclear factor- $\kappa \mathrm{B} / \mathrm{Rel}$ expression and the pathogenesis of breast cancer. J Clin Invest 100:2952-2960.

Sovak MA, Arsura M, Zanieeski G, Kavanagh KT, and Sonenshein D (1999). The inhibitory effects of transforming growth factor $\beta 1$ on breast cancer cell proliferation are mediated through regulation of aberrant nuclear factor- $\kappa \mathrm{B} /$ Ral expression. Cell Growth Diff 10:537-544.

Sun SC, Ganchi PA, Beraud C, Ballard DW, and Greene WC (1994). Autoregulation of the NF- $\kappa$ B transactivator Rel A (p65) by multiple cytoplasmic inhibitors containing ankyrin motifs. Proc Natl Acad Sci USA 91:1346-1350.

Thanos D and Maniatis T (1995). NF-kappa B: A lesion in family value. Cell 80:529-532.

Tjandrawinata RR, Dahiya R, and Hughes-Fulford M (1997). Induction of cyclooxygenase-2 mRNA by prostaglandin $\mathrm{E}_{2}$ in human prostatic carcinoma cells. Br J Cancer 75:1111-1118.

Traenckner EB, Pahl HL, Henkel T, Schmidt KN, Wilk S, and Baeuerle PA (1995). Phosphorylation of human Icon serines 32 and 36 controls $I_{\kappa} \mathrm{B} \alpha$ proteolysis and NF- $\kappa \mathrm{B}$ activation in response to diverse stimuli. EMBO J 14:2876-2883.

Wang CY, Mayo MW, and Baldwin AS Jr (1996). TNF- and cancer therapy-induced apoptosis: Potentiation by inhibition of NF- $\kappa$ B. Science 274:784-787.
Williams CW and Du Bios RN (1996). Prostaglandin endoperoxide synthase: Why two isoforms? Am J Physiol 270:393400.

Wu M, Lee H, Bellas RE, Schauer SL, Arsura M, Katz D, FitzGerald MJ, Rothstein TL, Sherr DH, and Sonenshein GE (1996). Inhibition of NF- $\kappa B /$ Rel induces apoptosis of murine $B$ cells. EMBO J 15:4682-4690.

Wulczyn FG, Krappmann D, and Scheidereit C (1996). The $\mathrm{NF}-\kappa \mathrm{B} / \mathrm{Rel}$ and $\mathrm{I}_{\kappa} \mathrm{B}$ gene families: Mediators of immune response and inflammation. $\mathrm{J}$ Mol Med 74:749-769.

Yamamoto $M$, Aoyagi $M$, Fukai N, Matsushima $\mathrm{Y}$, and Yamamoto $K$ (1999). Increase in prostaglandin $E_{2}$ production by interleukin-1 beta in arterial smooth muscle cells derived from patients with moyamoya disease. Circ Res 85:912-930.

Yamamoto K, Arakawa T, Ueda N, and Yamamoto S (1995). Transcriptional roles of nuclear factor $\kappa \mathrm{B}$ and nuclear factorinterleukin- 6 in the tumor necrosis factor $\alpha$-dependent induction of cyclooxygenase-2 in MC3T3-E1 cells. J Biol Chem 270:31315-31320.

Yang X, Bialik S, Jones BE, Limuro Y, Kitsis RN, Srinivasan A, Brenner DA, and Czaja MJ (1998). NF- $\kappa$ B inactivation converts a hepatocyte cell line TNF- $\alpha$ response from proliferation to apoptosis. Am J Physiol 275:C1058-C1066.

Zar BH (1984). Biostatistical analysis. Englewood Cliffs: Prentice-Hall.

Zimmermann KC, Sarbia M, Weber AA, Borchard F, Gabbert $\mathrm{HE}$, and Schror K (1999). Cyclooxygenase-2 expression in human esophageal carcinoma. Cancer Res 59:198-204. 